\title{
Minimally invasive treatment of dental erosions in gastro-esophageal reflux disease
}

\author{
Tratamentul minimum invaziv al eroziunilor dentare în \\ boala de reflux gastro-esofagian
}

\author{
Andrei Picos', Ioana Chifor ${ }^{1}$, Alina Rotar', Andreea Răchişan², Alina Monica Picos ${ }^{1}$ \\ ${ }^{1}$ Facultatea de Medicină Dentară, Universitatea „Iuliu Haţieganu“, Cluj-Napoca, România \\ ${ }^{2}$ Facultatea de Medicină şi Farmacie, Universitatea „Iuliu Haţieganu“, Cluj-Napoca, România
}

\begin{abstract}
Digital planning based on professional oral photographs and films is needed in order to realise minimal invasive treatments of dental erosions (DE) in gastroesophageal reflux disease (GERD). In the first stage a wax-up is made, followed by dental mock-up, in order to adjust functional and aesthetics factors and to guide the dental preparations. Composite, ceramic materials and modern cements offer the possibility of restoring affected functions like aesthetics, fonation and mastication, keeping healthy dental tissue almost
\end{abstract} intact.

Keywords: minimally invasive treatment, dental treatment, gastroesophageal reflux disease, dental erosion

\section{REZUMAT}

Pentru a realiza tratamentul minimum invaziv al eroziunilor dentare (ED) în boala de reflux gastroesofagian (BRGE), este necesară o planificare digitală pe baza fotografiilor și filmărilor profesionale intraorale. S-a efectuat în prima etapă wax-up pe modelele de studiu, urmând etapa de mock-up, care ghidează efectuarea modificărilor estetice și funcţionale. S-au utilizat materiale compozite și materiale ceramice pentru restau-rarea funcţiilor afectate, respectiv cea estetică, fonaţia și masticaţia, păstrând ţesuturile dentare restante aproape intacte.

Cuvinte cheie: tratament minimum invaziv, tratament dentar, boală de reflux gastroesofagian, eroziune dentară

\section{INTRODUCERE}

Respectul față de țesuturile dentare sănătoase impulsionează practicienii să încerce noi metode de tratament pentru a le conserva. Desigur, noile proceduri trebuie testate cu mijloacele care ne stau la dispoziție şi urmărite în timp, pentru a confirma succesul sau pentru a corecta eventualele greşeli. Materialele ceramice şi compozite sunt folosite de mult timp în stomatologie, dar tehnicile noi, adezive, au ajuns la performanța de a crea o legătură cu structurile dentare dure bazată pe formarea unui strat hibrid. Această legătură are valori ale aderenței similare cu cea dintre smalțul şi dentina dinţilor naturali. Aceasta înseamnă că dintele uzat poate fi reconstituit (în anumite limite) păstrându-i vitalitatea şi redându-i morfologia şi dimensiunea iniţială. Una dintre metode este numită "sandwich" şi presupune utilizarea ceramicii şi a compozitelor pe acelaşi dinte pentru reconstrucția lui coronară (1). Progresul calitativ înregistrat în ultimii ani în rândul cimenturilor de fixare de lungă durată a extins indicațiile fibrelor de sticlă, ale ceramicii şi ale compozitelor (2).

Există numeroase opțiuni terapeutice ale ED descrise în ultimii ani, care pot varia între simple reconstrucții dentare directe şi tratamente protetice complexe de reabilitare orală. Dintre acestea, unele au fost verificate şi acceptate de comunitatea internațională ca un nou standard terapeutic, altele ridi- 
că încă semne de întrebare referitor la rezistența în timp, fiind considerate încă experimentale şi prezentând un grad crescut de risc (3).

Acest articol îşi propune prezentarea unor tratamente minimum invazive moderne ale eroziunilor dentare (ED), care permit reconstrucții dentare fără îndepărtarea țesuturilor sănătoase, utilizând materiale ceramice şi compozite şi folosind adeziunea colajelor cu cimenturi răşină de ultimă generație. Metodele clasice sunt acceptate în continuare ca fiind corecte din punct de vedere al rezistenței în timp, dar care se asociază cu sacrificii semnificative de țesut dentar dur, devitalizarea dinților în scop protetic şi cu o estetică inferioară (4). În lucrarea de faţă s-au urmărit descrierea şi aplicarea tehnicilor moderne minimum invazive de tratament al ED utilizând materialele protetice cele mai performante.

\section{MATERIALE ŞI METODĂ}

Tratamentele minimum invazive ale ED s-au bazat pe tehnici adezive şi au restaurat dinții afectați cu fațete dentare, onlay-uri ceramice sau reconstrucții coronare totale directe (cu materiale compozite) sau indirecte (cu materiale compozite sau ceramice) (5). O variantă de tratament se referă la protezarea fixă pe implanturi, care, deşi presupune o tehnică chirurgicală invazivă, protejează țesuturile dinților vecini edentației, care rămân intacte, şi menține mai bine structurile osoase în care sunt inserate prin forțele exercitate asupra lor.

Pacienții aleşi pe baza diagnosticului de BRGE (boala de reflux gastroesofagian) au prezentat leziuni erozive dentare specifice sau edentații parțiale. Cuantificarea eroziunilor dentare s-a făcut prin calcularea indicelui BEWE (Basic Erosive Wear Examination). Acesta este indicele de evaluare preferat şi acceptat de comunitatea stomatologică în ultimii ani, în care se alocă valoarea 0 când nu există lipsă de țesut dentar, valoarea 1 în pierderea superficială la nivelul smalțului, valoarea 2 în pierderea smalțului cu descoperirea localizată a dentinei, dar distrucția coronară este sub $50 \%$ din volumul coronar, şi valoarea maximă de 3 , când lipsa de țesut dentar cu dentina expusă este extinsă pe mai mult de $50 \%$ din suprafața dintelui. Aceste valori se apreciază în sextanții corespunzători celor două arcade dentare şi fiecărui sextant i se acordă valoarea BEWE a dintelui cu cel mai avansat grad de di- strucție coronară. Valoarea globală reprezentând scorul final al pacientului se obține prin însumarea sextanților, orientând medicul asupra stadiului de gravitate al leziunilor (scorul maxim este 18). Valoarea scorului final se poate clasifica în grupe de risc astfel: scorul cuprins între 0 şi 2 se încadrează în grupa pacienților fără risc, scorul între 3 şi 8 se încadrează în risc scăzut, scorul între 9 şi 13 reprezintă un risc mediu, iar scorul $>14$ reprezintă un risc crescut de distrucție coronară (6).

Analiza cazurilor utilizează, pe lângă examenul clinic, examinări complementare, respectiv radiografii, fotografiile faciale şi intraorale precum şi filmările profesionale necesare pentru planificarea digitală a tratamentului şi alegerea, împreună cu pacientul, a variantei terapeutice estetice acceptate de acesta. S-au realizat modele de studiu maxilare şi mandibulare. În laborator s-a lucrat pe articulatoare programabile, utilizând înregistrarea ocluziei cu arcul facial, în relație centrică în cazul reabilitării totale. Dimensiunea verticală de ocluzie în cazul pacienților cu BRGE şi ED avansate este diminuată din cauza pierderii țesuturilor de la nivelul suprafețelor ocluzale, dar există un mecanism de compensare naturală prin egresie sau extruzie, care complică tratamentul.

Refacerea estetică a dinţilor grav afectaţi de ED a impus crearea spațiului necesar înălțimii coronare normale. Tatonarea adaptării pacientului la înălțarea ocluziei s-a făcut cu gutiere, timp de câteva săptămâni, până la o dimensiune de confort la care avem spațiul necesar reconstrucțiilor dentare. S-a realizat înălțarea cu $1 \mathrm{~mm}$ a zonei posterioare, obținând $3 \mathrm{~mm}$ de spațiu in zona anterioară. Pacienții au beneficiat de gutiere de protecție nocturnă pentru buna menținere a rezultatelor tratamentului.

Pentru rezolvarea cazurilor estetice, studiul prezent a folosit un program digital (Digital Smile Design), care pune la dispozitia clinicianului diferite tipuri de morfologie dentară, pentru o alegere optimă care să refacă individualizat armonia facială. De asemenea, ajută să planificăm în detaliu modificările de poziție necesare pentru a obține estetica dorită şi furnizează un ghid pentru eventualele şlefuiri dentare. Modelele pot fi vizualizate de pacient pe calculator, prin suprapunere directă pe fotografiile efectuate în cabinet cu ajutorul unor instrumente calibrate. Ele permit o mai bună informare a pacientului cu privire la înțelegerea planului de trata- 
ment înainte de a-şi da acordul asupra planului de tratament (7).

În acest mod se pot cunoaşte cu exactitate toate modificările necesare (preparațiile dentare pot fi minimum invazive dacă se realizează pe mock-up): dimensiunile şi volumele tuturor dinților incluşi în tratament, necesitatea intervențiilor chirurgicale, de coborâre a buzei superioare sau gingivale (traiectul acestor repere liniare estetice care unesc punctele Zenith ale dinţilor şi distanța la care se va efectua incizia față de coletul dentar, necesar corectării surâsului gingival), poziționarea dinților şi alegerea punctelor de contact.

\section{DISCUŢII ŞI REZULTATE}

În prima etapă s-a efectuat wax-up de ceară pe modelele de studiu, conform indicațiilor date de medic ulterior analizei faciale şi intraorale, tehnicianul dentar a realizat prefigurarea în ceară pe modelele de studiu a variantei finale de design, convenabilă estetic şi funcțional. În multe cazuri este necesară realizarea mai multor wax-up-uri pentru a ajunge la o varianta convenabilă.

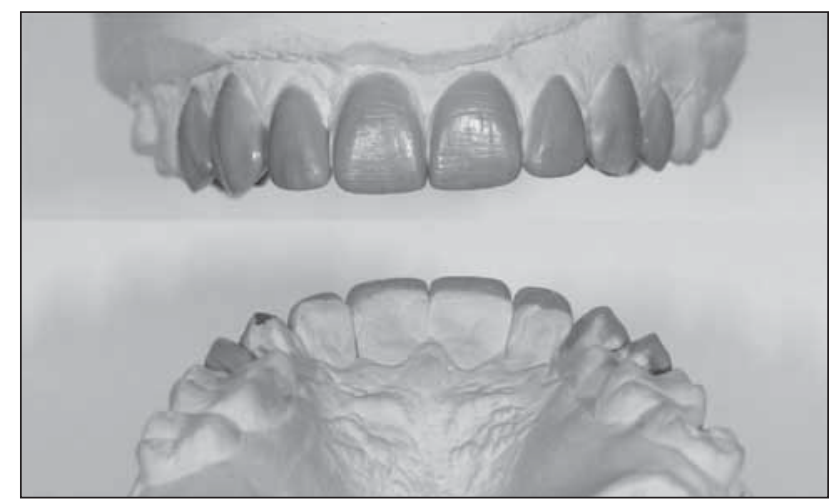

FIGURA 1. Wax-up din ceară pe modelele de studiu

În vederea realizării mock-up-ului direct în cabinet, modelele au fost amprentate cu siliconi de adiție Putty (Fig. 2). În această amprentă care reprezintă modelul negativ care prefigurează varianta protetică finală, am introdus un material compozit ales conform culorii dorite de pacient. Amprenta încărcată cu răşină compozită s-a aplicat în cavitatea orală, iar după priză s-a îndepărtat suportul de Putty, materialul compozit rămânând pe dinţii pacientului. Astfel, se obține prima previzualizare în cavitatea orală, numită mock-up, de către medic şi pacient, a lucrărilor finale. Acestea ghidează efectuarea modificărilor estetice şi funcționale finale, medicul în această etapă poate îndepărta sau adăuga material în zonele dorite sau poate corecta culoarea aleasă (Fig. 3).

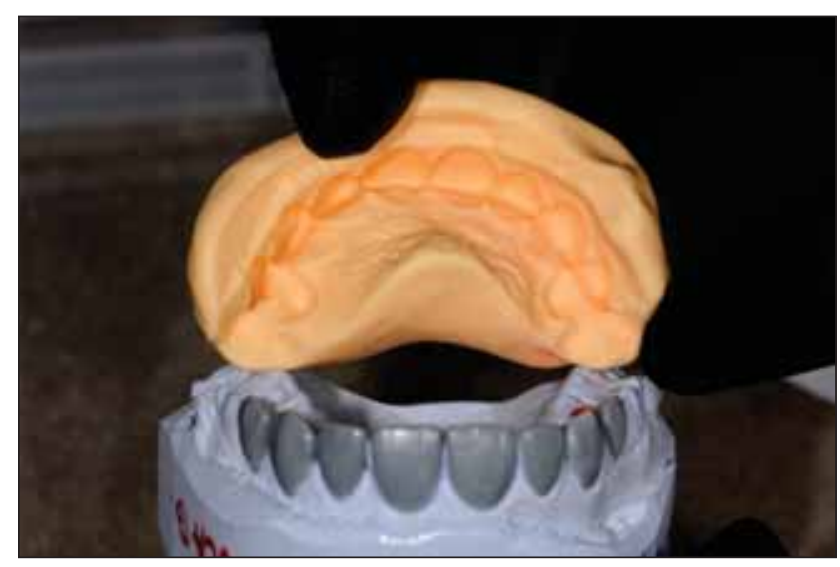

FIGURA 2. Amprentarea cu silicon tip Putty a modelului cu wax-up

În cazul redimensionării DVO, pacientul rămâne până la o lună cu lucrările provizorii (realizate inclusiv pe zona posterioară ocluzală sau utilizând gutiere cu grosime egală cu dimensiunea de înălţare a zonei posterioare) pentru a se putea hotărî asupra esteticii şi a testa adaptarea la noua dimensiune verticală de ocluzie. Ulterior, s-a amprentat arcada maxilară şi mandibulară pentru a transmite tehnicianului modificările făcute în cabinet.

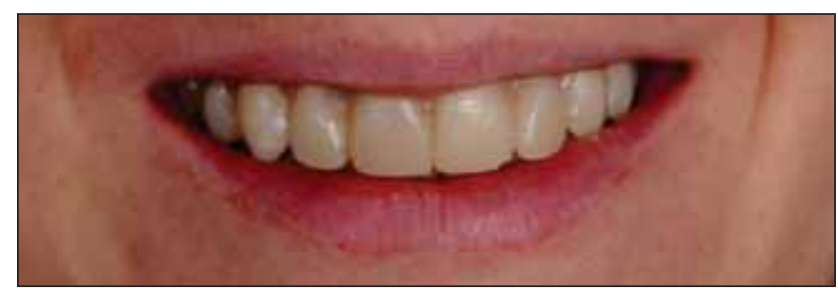

FIGURA 3. Mock-up realizat direct în cavitatea orală pentru acceptul pacientului şi verificarea funcțională a planului protetic prefigurat pe wax-up

Metodele minimum invazive folosesc lucrarile provizorii ca un ghid pentru şlefuirea dinţilor. În acest fel, se realizează preparațiile dentare după realizarea şanţurilor de ghidare cu freze ghid pe suprafețele dentare acoperite de materialul compozit provizoriu, aşa încât se îndepărtează strictul necesar pentru realizarea grosimii minime a lucrărilor protetice integral ceramice (grosimea ceramicii 0,3-0,5 mm) şi asigurarea unui profil de emergență corect la tranziția dintre porțiunea coronară a dintelui şi cea radiculară (Fig. 4). Limitele preparațiilor răman pe cât posibil în smalț şi nu vor ajunge la 
stratul dentinar, în scopul asigurării unei adeziuni de bună calitate a colajului lucrărilor protetice integral ceramice.

După finalizarea acestei etape, se îndepărtează materialul provizoriu compozit de pe dinți, constatându-se protecția țesuturilor dentare sănătoase care rămân neatinse în unele zone care nu necesită preparație pentru a atinge rezultatele previzionate de wax-up.

Finisarea limitelor preparațiilor se face cu anse diamantate fine, ataşate la piesa cu ultrasunete, pentru a asigura o adaptare marginală microscopică, fără infilltrații ulterioare (8).

Prin metoda expusă mai sus, freza atinge dintele pe care se lucrează doar în zonele unde este strict necesar şi îndepartează minimum de substanță dentară, cu exactitate, atât cât este nevoie pentru confecționarea lucrărilor estetice definitive. Amprentarea finală s-a realizat cu siliconi de adiție, după dilatare sulculară cu fir de retracție gingivală necesară pentru înregistrarea fidelă a limitelor preparațiilor dentare.

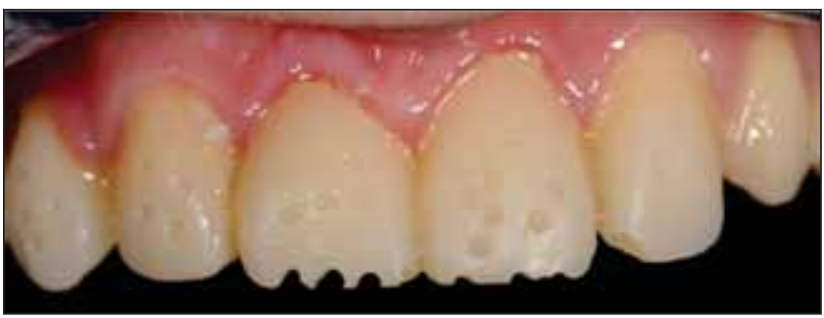

FIGURA 4. Trasarea ghidajelor cu freze tip ghid pe mock-up-ul direct în vederea realizarii preparațiilor dentare minimum invazive

Pentru cimentarea lucrărilor ceramice sau compozite s-au folosit cimenturi răşină moderne (ex: 3M Relyx, Bisco Choice), care au asigurat formarea unui strat hibrid între dinte şi material cu o rezistență superioară la solicitări. Folosirea acestor materiale a permis renunțarea la retenția mecanică a lucrărilor protetice. Pentru obținerea unei adeziuni optime, suprafețele colate au fost pregătite corect, respectând cu strictețe protocolul standard de colaj (foarte importantă este evitarea contaminării suprafețelor după tratamentul aplicat, respectiv acid ortofosforic pentru țesuturi dentare, acid fluorhidric pentru ceramică feldspatică, sablare pentru oxid Zr). Ceramica folosită a fost de tipul E-max disilicat de litiu, cu o rezistență la solicitare de 500 MPa (Fig. 5). Ceramica feldspatică, deşi are esteti- ca optimă, este indicată în special în zona frontală a arcadelor dentare, având rezistența de aprox 150 Mpa. Materialele compozite au rezistență de aproximativ $50 \mathrm{Mpa}(9)$.

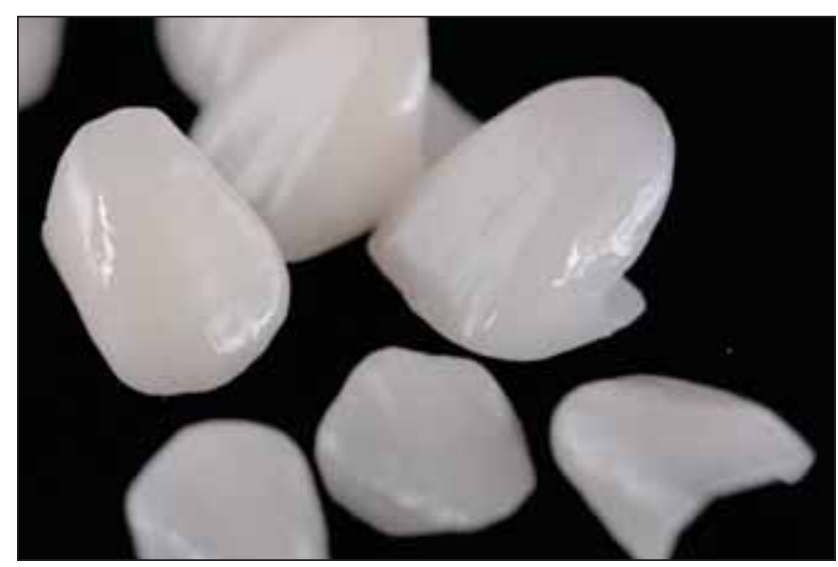

FIGURA 5. Fațete ceramice E-max disilicat de litiu

În cazul edentațiilor, variantele de tratament supraimplantar se încadrează în conceptul minimum invaziv pe care 1-am aplicat şi presupun etapele uzuale de tratament protetic supraimplantar. Această variantă de tratament păstrează intacți dinții vecini spațiului edentat, care, prin alegerea unui plan de tratament convențional, ar fi şlefuiți sau chiar devitalizați. Metoda de tratament s-a ales în funcție de particularitațile individuale şi de gravitatea leziunilor. S-au utilizat materiale compozite (GC) şi materiale ceramice (E-max Ivoclar) pentru realizarea lor în scopul restaurării funcțiilor afectate, respectiv estetica, fonaţia, autoîntreținerea şi masticația (10).

Cazurile tratate au rezultate bune atât din punct de vedere estetic, cât şi funcțional. Pentru siguranța succesului terapeutic şi menținerea lui sunt extrem de importante documentarea completă a cazurilor şi urmărirea lor postterapeutică, prin controale periodice la intervale de timp individualizate şi pe termen îndelungat $(11,12)$. Utilizarea materialelor compozite şi ceramice prin tehnici adezive minimum invazive, în locul materialelor metalo-ceramice, s-a dovedit a fi un succes, atât datorită respectului față de țesuturile dure dentare sănătoase restante, cât şi calității estetice şi reducerii disconfortului psihic prin şedințe de lucru mai puţin laborioase şi mai scurte. Utilizarea programelor digitale a permis o mai eficientă colaborare cu pacientul şi o implicare a acestuia în deciziile estetice, ceea ce îi induce acestuia o creştere a încrederii în rezultatul final (Fig. 6). 


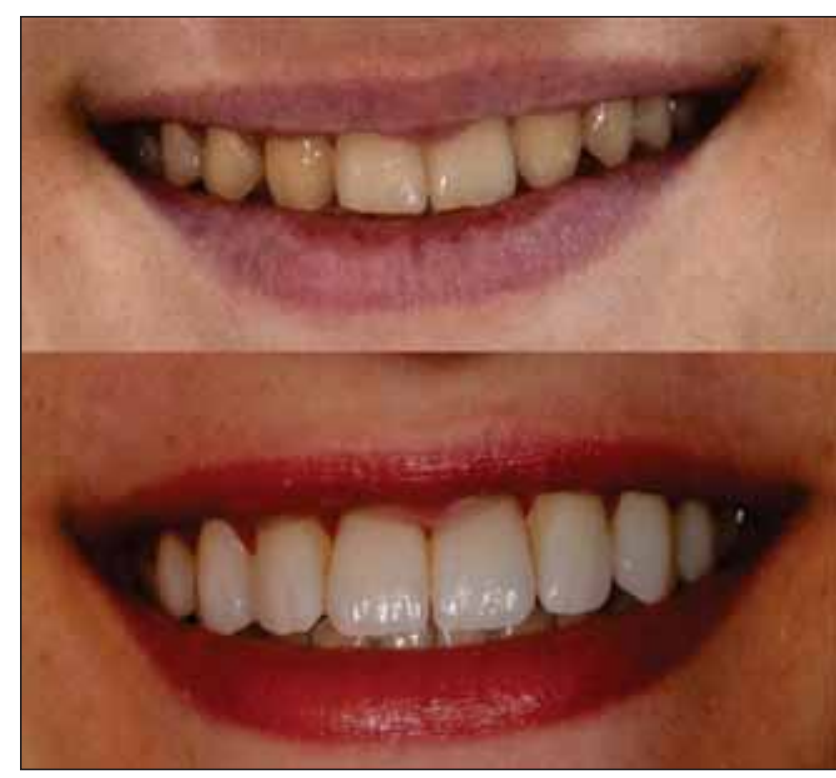

FIGURA 6. Restaurarea zâmbetului prin fațetare ceramică după finalizarea tratamentului protetic minimum invaziv "Before and after"

Ambele variante conceptuale de tratament, atât cea minimum invazivă, cât şi cea convențională, pot fi considerate corecte datorită restabilirii funcțiilor pierdute şi rezistenței pe parcursul celor trei ani; metoda minimum invazivă - care utilizează materialele compozite având un grad redus de rezistență la uzură comparativ cu masele ceramice sugerează o relativă rezervă privind menținerea rezultatelor în timp.

În eroziunile dentare uşoare, localizate doar la nivelul smalțului, se pot utiliza reconstrucții directe din materiale compozite.

În cazurile cu ED medii (BEWE = 9-13) şi avansate (BEWE > 14), unde dentina este expusă agresiunii orale şi înălţimea coronarei este redusă uneori la 3-4 mm, sunt necesare tratamentele protetice indirecte, care utilizează atât compozitele pe suprafețele ocluzale posterioare sau palatinale anterioare, cât şi ceramica pe suprafețele ocluzale sau vestibulare ale dinților anteriori (metoda "sandwich" de recuperare a dinților frontali grav erodați).

Desigur, prețul de cost al tratamentelor minimum invazive este superior tratamentelor clasice, acesta fiind uneori criteriul principal al opțiunii pacientului, mai ales la tineri. Beneficiile acestora pe termen lung sunt reprezentate în principal de o mai bună menținere a componentelor ADM, aspect extrem de important, mai ales la tineri. Aceste avantaje sunt înțelese atunci când tratamentul este clar explicat pacientului, pe înțelesul lui, astfel încât să poată discerne adecvat între propunerile terapeutice.

Metodele de tratament minimum invaziv permit reconstrucția dinților cu eroziuni dentare incipiente sau medii, menținând integre țesuturile dentare sănătoase restante. Cimenturile moderne permit o bună adeziune printr-o puternică legătură între suprafețele dentare şi materialele ceramice sau compozite, prin formarea stratului hibrid. Estetica ceramicii integrale sau chiar a materialelor compozite este superioară protezelor unitare sau parțiale fixe metalo-ceramice convenționale, care, la dinții grav afectați eroziv, cu retentivitatea pierdută şi riscul de fracturare crescut, utilizează dispozitive corono-radiculare metalice pentru a obține retenția şi rezistența necesară.

Boala de reflux gastroesofagian este o afecțiune diagnosticată tot mai des în rândul tinerilor şi, din această cauză, este necesară acordarea unei atenții deosebite controalelor periodice şi surprinderii primelor semne de eroziune dentară, pentru diagnosticarea leziunilor dentare in stadii incipiente $(13,14,15)$. Totodată, cerințele estetice ale pacienților sunt crescute astăzi, ca şi dorința de a prezerva integre țesuturile dentare sănătoase, clinicianul fiind obligat să ofere o alternativă protezelor fixe clasice, unitare sau plurale, considerate timp îndelungat varianta ,standard“ de tratament. Noul concept minimum invaziv înlocuieşte în mare măsură retenția mecanică prin adeziunea noilor tipuri de lucrări integral ceramice minimaliste, la țesuturile dentare sănătoase, păstrând vitalitatea dinţilor (16).

Lucrările integral ceramice cimentate conform protocolului cu cimenturi răşină nu au prezentat accidente postterapeutice. Lucrările metalo-ceramice pot prezenta accidente mecanice prin desprinderea unui fragment ceramic de pe infrastructura metalică. Aceasta susține ideea că aderența la nivelul interfeței ceramică-dinte este mai puternică decât cea existentă la interfața ceramică-aliaj metalic.

Tratamentele minimum invazive au un preț superior tratamentelor clasice, dar păstrează vitalitatea dinților şi asigură o menținere superioară a componentelor ADM, aspect extrem de important, mai ales la tineri.

Prețul de cost al tratamentelor restauratorii dentare este mai redus în cazul diagnosticării ED în stadii incipiente, de aceea se impune o bună monitorizare a pacienților cu BRGE prin controale peri- 
odice la intervale de timp individualizate, de la 3 la 6 luni (15).

Gradul de satisfacţie din punct de vedere estetic al pacienților tratați minimum invaziv cu lucrări integral ceramice este mai ridicat decât în cazul pacienților trataţi cu lucrări metalo-ceramice. Pacienții tratați minimum invaziv prezintă o ocluzie funcțională, aceasta asigurând premisele necesare unei bune menţineri în timp a rezultatelor terapeutice (3).

\section{CONCLUZII}

Buna stabilitate a lucrărilor observată în studiul prezent se datorează cimenturilor răşină moderne,

\section{BIBLIOGRAFIE}

1. Colon P, Lussi A. Minimal intervention dentistry: part 5. Ultra-conservative approach to the treatment of erosive and abrasive lesions. Br Dent J. 2014;216(8):463-8

2. Lussi A, Jaeggi T. L'erosion dentaire - diagnostique evaluation du risque, prevention, traitement. 2012:55-67.

3. Magne P, Magne M, Belser UC. Adhesive restorations, centric relation, and the Dahl principle: minimally invasive approaches to localized anterior tooth erosion. Eur J Esthet Dent. 2007 Autumn;2(3):260-73.

4. Eccles JD. The treatment of dental erosion. J Dent. 1978:6:217-21.

5. Picoş AM. Eroziunea dentara in boala de reflux gastroesofagian. Editura "luliu Hatieganu" Cluj Napoca 2014

6. Bartlett D, Ganb C, Lussi A. Basic erosive wear examination (BEWE): a new scoring system for scientific and clinical needs. Clin Oral Invest 2008;12;S65-S68

7. Picoş A, Rachisan AL, Dadarlat A. Minimally Invasive Dental Treatment Using Composites and Ceramics in BRGE Diagnoses Patients. Materiale Plastice, 2018, 55( 2).

8. Faus-Matoses I, Solá-Ruiz F. Dental Preparation with Sonic vs High-speed Finishing: Analysis of Microleakage in Bonded Veneer Restorations. Journal of Adhesive Dentistry. 2014, 16 (1): 29-34 care permit o bună adeziune între suprafețele dentare şi materialele ceramice sau compozite, prin formarea stratului hibrid, care la nivel microscopic arată ca o rețea tridimensională care penetrează structura dentară.

Utilizarea ceramicii integrale şi a materialelor compozite a asigurat o estetică naturală, superioară protezelor unitare sau parțiale fixe metalo-ceramice convenţionale, şi elimină trauma psihică legată de intervențiile protetice numeroase, laborioase şi obositoare.

Conflict of interest: none declared Financial support: none declared

9. Magne P, Belser U. Bonded Porcelain Restorations in the Anterior Dentition: ABiomimeticApproach. Quintessence International, 2003, p. 336

10. Picoş AM, Picoş A, Nicoara P, Craitoiu MM., Dental Erosion in a Partially Edentulous Patient with Gastroesophageal Reflux Disease: A Case Report. Clujul Med., 87, nr. 4, 2014, p. 284-87

11. Lussi A, Portmann P, Burhop B. Erosion on abraded dental hard tissues by acid lozenges: an in situ study. Clin Oral Invest 1997;1:191-194.

12. Lussi $A$, Jaeggi T, Scharer $S$. The influence of different factors on in vitro enamel erosion. Carries Res 1993; 27: 387-393.

13. Lussi A, Jaeggi T. Erosion - diagnosis and risk factors. Clin Oral Investig. 2008 Mar;12 Suppl 1:S5-13.

14. D'Incau E, Saulue P. Understanding dental wear. J. Dent. Anomalies and Orthodontics, 2013; 15, (1): 104-123.

15. Lussi A, Hellwig E. Risk assessment and preventive measures. In: Lussi A (ed) Dental erosion. From diagnosis to therapy. Karger, Basel, (2006), pp 190-199

16. Picoş A, Badea ME, Dumitrascu DL. Dental erosion in gastro-esophageal reflux disease. A systematic review. DOI: 10.15386/cjmed-1017 , 2018 